\title{
AN EARLY JURASSIC SAUROPOD TOOTH FROM PATAGONIA (CAÑADÓN ASFALTO FORMATION): IMPLICATIONS FOR SAUROPOD DIVERSITY
}

\author{
JOSÉ L. CARBALLIDO1 \\ FEMKE M. HOLWERDA² \\ DIEGO POL ${ }^{1}$ \\ OLIVER W. M. RAUHUT²
}

\begin{abstract}
${ }^{1}$ CONICET-Museo Paleontológico Egidio Feruglio, Fontana 140, 9100 Trelew, Chubut, Argentina.
${ }^{2}$ Bayerische Staatssammlung für Paläontologie und Geologie, Department of Earth and Environmental Sciences, and GeoBioCenter, Ludwig-MaximiliansUniversity, Richard-Wagner-Straße 10, 80333 Munich, Germany.
\end{abstract}

Recibido: 4 de octubre de 2017 - Aceptado: 17 de noviembre de 2017

Para citar este artículo: José L. Carballido, Femke M. Holwerda, Diego Pol, and Oliver W. M. Rauhut (2017). An Early Jurassic sauropod tooth from Patagonia (Cañadón Asfalto Formation): implications for sauropod diversity. Publicación Electrónica de la Asociación Paleontológica Argentina 17 (2): 50-57.

Link a este artículo: http://dx.doi.org/10.5710/PEAPA.17.11.2017.249

DESPLAZARSE HACIA ABAJO PARA ACCEDER AL ARTÍCULO

Otros artículos en Publicación Electrónica de la APA 17(1):

\section{Patterer, Zucol \& Passeggi}

ANÁLISIS FITOLITICOS EN SUELOS FORMADOS SOBRE ANTIGUAS TERRAZAS DEL RÍO URUGUAY (COLÓN, ENTRE RÍOS): PRIMERA EVIDENCIA DE RETRACCIÓN DE LOS PALMARES DE BUTIA YATAY (MART.). BECC.

\section{Vizcaíno et al.}

ON AN ALBUM OF PHOTOGRAPHS RECORDING FOSSILS IN THE "OLD COLLECTIONS" OF THE MUSEO DE LA PLATA AND AMEGHINO'S PRIVATE COLLECTION AT THE BEGINNING OF THE XXTH CENTURY

Asociación Paleontológica Argentina Maipú $6451^{\circ}$ piso, C1006ACG, Buenos Aires

República Argentina

Tel/Fax (54-11) 4326-7563 Web: www.apaleontologica.org.ar

\section{Deschamps et al.}

BIOSTRATIGRAPHIC REASSIGNMENT OF THE NEOGENE CAENOLESTINES (MARSUPIALIA) OF THE PAMPEAN REGION: THE CASE OF PLIOLESTES TRIPOTAMICUS REIG, 1955 


\title{
AN EARLY JURASSIC SAUROPOD TOOTH FROM PATAGONIA (CAÑADÓN ASFALTO FORMATION): IMPLICATIONS FOR SAUROPOD DIVERSITY
}

\author{
JOSÉ L. CARBALLIDO, FEMKE M. HOLWERDA², DIEGO POL, AND OLIVER W. M. RAUHUT²
}

1CONICET-Museo Paleontológico Egidio Feruglio, Fontana 140,9100Trelew, Chubut, Argentina. jcarballido@mef.org.ar; dpol@mef.org.ar

²Bayerische Staatssammlung für Paläontologie und Geologie, Department of Earth and Environmental Sciences, and GeoBioCenter, Ludwig-Maximilians-University, Richard-Wagner-Straße 10, 80333 Munich, Germany.o.rauhut@Irz.uni-muenchen.de; f.m.holwerda@gmail.com

\begin{abstract}
Eusauropods were a group of herbivorous dinosaurs that evolved during the Early Jurassic and dominated the terrestrial ecosystems throughout the Jurassic and Cretaceous. A peak of diversity is represented by the Late Jurassic, when most of the lineages of the derived clade, Neosauropoda, are represented. Different lineages of eusauropods differ in several morphological aspects, including a great diversity in gathering strategies, inferred by their dentition morphology and wear facets. Here we describe a new tooth morphotype that can be well differentiated from any other tooth recovered from the Cañadón Asfalto Formation (Lower-Middle Jurassic). Therefore, this new tooth morphology increases the evidence of a high diversity of sauropods during that time as well as providing evidence of advanced characters in the dentition of some Early Jurassic sauropods (e.g., subcylindrical and narrow crowns with single apical wear facet).
\end{abstract}

Key words. Sauropoda. Wear facets. Narrow-crowned. Broad-crowned. Argentina.

Abstract. UN DIENTE DE SAURÓPODO DEL JURÁSICO TEMPRANO DE PATAGONIA (FORMACIÓN CAÑADÓN ASFALTO): IMPLICANCIAS PARA LA DIVERSIDAD DE SAURÓPODOS. Los eusaurópodos fueron un grupo de dinosaurios herbívoros que evolucionaron durante el Jurásico Temprano y que dominaron los ecosistemas terrestres a lo largo de todo el Jurásico y Cretácico. Durante el Jurásico Superior se observa un pico en su diversidad, cuando la mayoría de los linajes de Neosauropoda, un clado derivado, se encuentran bien representados. Los diferentes linajes de Eusauropoda difieren en distintos aspectos morfológicos, incluyendo una gran diversidad de estrategias de alimentación, inferidas por la morfología de sus dientes y las facetas de desgaste. Aquí describimos un nuevo morfotipo de diente que puede ser bien diferenciado de cualquier otro diente recuperado de la Formación Cañadón Asfalto (Jurásico Inferior a Medio). Por lo tanto, este nuevo morfotipo incrementa la evidencia de diversidad de saurópodos durante ese momento, dando cuenta de caracteres derivados en la dentición de algunos saurópodos del Jurásico Inferior (e.g., dientes sub-cilíndricos con coronas angostas y una única faceta de desgaste apical).

Palabras clave. Sauropoda. Facetas de desgaste. Coronas angostas. Coronas anchas. Argentina.

EUSAUROPOD dinosaurs were the dominant terrestrial megaherbivores throughout the Jurassic and Cretaceous, especially in the southern hemisphere. After their origin in the Early Jurassic, eusauropods reached their maximum diversity by the Late Jurassic (Mannion et al., 2011), when most lineages of the derived clade Neosauropoda are first recorded. Although the origins of Neosauropoda are commonly traced back to the Middle Jurassic (Remes, 2006), neosauropods from this age are extremely rare, fragmentary, and have debated affinities. It is only by the Late Jurassic that a large number of neosauropod taxa are well known (see Upchurch et al., 2004). By this time, neosauropods were already highly diversified, as representatives of their major lineages are recorded in different regions of the world.

The separate lineages of eusauropods differ (among other features) in their food-gathering strategies (Upchurch and Barrett, 2000), inferred from their dentition. Whereas D-shaped and broad-crowned teeth with V-shaped wear facets are present in all non-neosauropodan eusauropods, cylindrical or subcylindrical, narrow-crowned teeth with a single major wear facet characterize two unrelated clades of neosauropods, Diplodocoidea and Titanosauriformes. The derived cylindrical or subcylindrical narrow-crowned dentition with a single apical wear facet has been first recorded 
in the Late Jurassic, when eusauropods occupied their greatest range of crown breadths and feeding habits (Chure et al., 2010).

Here we describe an isolated ovoid tooth, the crown of which is virtually unexpanded mesiodistally (MPEF-PV 10606), from the Cañadón Asfalto Formation. Radiometric dates in the Cañadón Asfalto Formation yielded a late Early Jurassic (Toarcian) age for the lower part of this unit (Cúneo et al., 2013). The tooth MPEF-PV 10606 was collected in the basal layers of the Cañadón Asfalto Formation, at the famous microvertebrate locality Queso Rallado (e.g., Rauhut et al., 2002; Rougier et al., 2007; Sterli, 2008; Pol et al., 2011; Cúneo et al., 2013). It therefore predates the first record of sauropods with ovoid unexpanded crowns with a single apical wear facet by at least 20 million years.

\section{INSTITUTIONAL ABBREVIATIONS}

MACN-CH, Museo Argentino de Ciencias Naturales "Bernardino Rivadavia"-Colección Chubut, Buenos Aires, Argentina; MPEF-PV, Museo Paleontológico "Egidio Feruglio" -Paleovertebrados, Trelew, Argentina; SMA, Sauriermuseum Aathal, Switzerland.

\section{DESCRIPTION}

The isolated tooth MPEF-PV 10606 preserves an almost complete crown, except for the extremely worn apex, the enamel layer along its mesial and distal margins, and the major part of its root. The missing part of the root is likely the product of resorption, an interpretation that is consistent with the significant wear observed in the crown (Fig. 1.2-3). Additionally, the root is worn as well, forming a deep concavity, especially in its mesial and distal surface (Fig. $1.2-3)$, which is similar in shape to that of heavily worn teeth of other sauropods (e.g., Camarasaurus Cope, 1877; SMA 0002).

The general shape of the tooth is clearly apicobasally elongated in relation to the mesiodistal width of the crown. The slenderness index (SI; Upchurch, 1998) is certainly greater than 1.8, but due to the extensive wear it is not possible to better estimate it. At the base of the crown, both the labial and the lingual surfaces are mesiodistally convex, so that the crown is subcircular in cross section (Fig. 1.4). Towards the apex, the crown gradually flattens labiolin- gually, so that its cross-section progressively changes from a circular shape to a labiolingually narrow ovoid shape (Fig. 1.4). At the preserved apex, the crown is approximately 1.8 times mesiodistally broader than labiolingually wide. The lingual and labial enamel coat is subequal in thickness, being approximately $0.7-0.8 \mathrm{~mm}$ at the level of the wear facet (Fig. 1.5-6). In labial and lingual views the crown is symmetrical (Fig. 1), making it impossible to determine which is the mesial or the distal margin. In distal and mesial views, the tooth is slightly asymmetrical since the lingual surface is more convex along the mesiodistal axis, as in other sauropods (e.g., Amygdalodon Cabrera, 1947; Dicraeosaurus Janensch, 1935-1936; Abydosaurus Chure et al., 2010).

As noted above, the enamel layer has not been preserved at the mesial and distal margins of the crown. However, the marginal surface of the dentine is rounded and well preserved, so that the original crown shape would only be slightly more expanded mesiodistally than it is preserved. The narrow profile of the crown differs from the broad-crowned condition of most non-neosauropod sauropods (Amygdalodon, Tazoudasaurus Allain et al., 2004, Patagosaurus Bonaparte, 1979, Mamenchisaurus Young, 1954; Carballido and Pol, 2010; Allain and Aquesbi, 2008; Bonaparte, 1986; Ouyang and Ye, 2002) and basal macronarians (Camarasaurus Cope, 1878; Madsen et al., 1995). Among basal sauropods, mesiodistally unexpanded tooth crowns are found in some taxa, such as Shunosaurus Dong et al., 1983 (Chatterjee and Zheng, 2002).

A single, high-angle (set at 70 degrees relative the long axis of the crown) wear facet is present on the labial side of the crown (Fig. 1.2-3). Labial wear facets are commonly found in the teeth of the dentaries of other eusauropods (Shunosaurus, Giraffatitan Janensch, 1914; Chatterjee and Zheng, 2002; Janensch, 1935-1936). Most of the dentine is poorly preserved and it is not possible to observe the presence of scratches or pits on its worn surface. Slightly developed mesial and distal wear facets are present close to the apex of the crown (Fig. 1.5). Thus, MEPF-PV 10606 has two planar and poorly developed marginal wear facets, and a well-marked labial facet.

The outer enamel surface of the crown is heavily wrinkled (Fig. 1.7), except for the polished surfaces close to the wear facets, where the wrinkling might have been eroded 
by wear. The wrinkled pattern of this tooth has a series of apicobasally-aligned circular to subovoid pits, which are connected to each other by continuous and narrow sulci. The sulci are shallower than the pits and consequentially seem to be worn before the pits, as only few isolated pits are present on the apical polished surface (Fig. 1.3). The sulci are very gently undulating, and are discontinuous throughout the mid-section of the tooth surface. Unlike in teeth ascribed to Patagosaurus (Holwerda et al., 2015), the wrinkling at the base of this tooth is finer and shows smaller sulci and pits than at the mid-section. The pebbly wrinkling of the undetermined sauropod teeth MACN-CH 934 does show more pronounced enamel wrinkling patterns in the midsection of the teeth, however, these teeth are embedded in maxillae, and therefore the base of the tooth is not entirely visible as in the isolated tooth crown MPEF-PV 10606. Narrow grooves are present on the right margin (when the crown is observed in labial view) of the labial surface and on the left margin of the lingual surface of the crown (Figs. $1.1-3)$.

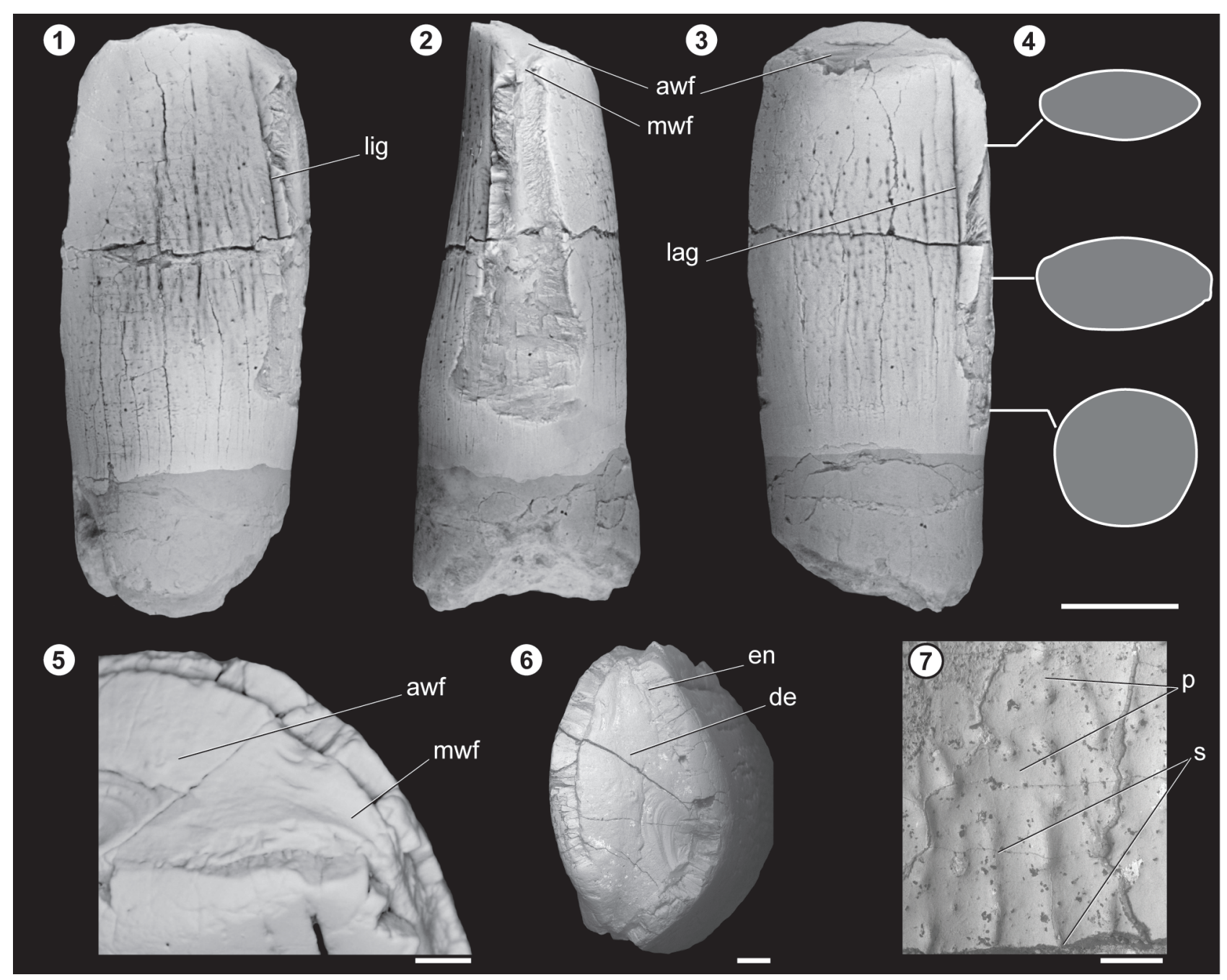

Figure 1. 1-7, MPEF-PV 10606; 1, lingual view; 2, left margin; 3, labial view; 4, cross section shapes; 5, close-up of the right surface of the wear facet; 6 , apical view; 7, close up of the enamel surface. awf, apical wear facet; en, enamel; de, dentine; lag, labial groove; lig, lingual groove; mwf, marginal wear facet; $p$, pits; $\mathbf{s}$, sulcus. Scale bar $=1-4=5 \mathrm{~mm} ; 5-7=0.5 \mathrm{~mm}$. 


\section{DISCUSSION}

\section{Taxonomic identification}

The most parsimonious position of the tooth here described was analyzed through a cladistic analysis using two different datasets (Carballido et al., 2017, Becerra et al., 2017, see Supplementary Material). Details of the analysis and its results are provided in the Supplementary Material. Eusauropod affinities. Eusauropods have long been characterized by the presence of teeth with a heavily wrinkled outer enamel surface, and wear facets (Salgado and Calvo, 1997; Wilson and Sereno, 1998). The tooth here described can be referred to the clade formed by Amygdalodon and more derived sauropods due the presence of a wrinkled outer enamel surface, well developed wear facets, and labial grooves, all of which have been identified as apomorphies of eusauropods (Wilson and Sereno, 1998) and their most closely related outgroups (Carballido and Pol, 2010).

Although a more basal position among sauropodomorphs should not be completely ruled out given the incompleteness of this specimen, the presence of derived characters indicates eusauropod affinities. In that sense, narrow crowned teeth with well-developed wear facets were described for the non-sauropodan sauropodomorph Yunnanosaurus Young, 1942 (Galton, 1985: fig. 6), but these teeth lack the wrinkled pattern here described. Additionally, whereas slender crowns were described for Melanorosaurus Haughton, 1924 neither of the teeth preserved in the complete skull present wear facets nor wrinkled pattern (Yates, 2007). Therefore, even when some of the characters observed in the isolated tooth could be observed in basal sauropodomorphs, none of the currently known basal sauropodomorphs shows the combination of derived characters observed in MPEF-PV 10606. Therefore, different positions among eusauropods are here discussed.

Possible neosauropod affinities. As noted above, MPEF-PV 10606 bears a combination of characters that are otherwise only known in neosauropods. Among these forms broadcrowned teeth represent the plesiomorphic condition as they are also present in most basal (non-neosauropod) eusauropods, and in basal species of Macronaria (Salgado and Calvo, 1997; Wilson, 2002; see Fig. 2). Narrow crowned teeth, with convex labial and lingual surfaces are present in derived macronarians (Titanosauriformes) and Diplodo- coidea (Barrett and Upchurch, 2005; see Fig. 2). These two groups of narrow-crowned neosauropods have a strongly modified kind of tooth-tooth occlusion that produces a single planar facet that extends on the labial and/or lingual surface of the apex of the crown. Furthermore, several basal titanosauriforms also have reduced marginal (mesial and distal) wear facets (e.g., Brachiosaurus Riggs, 1903, Nemegtosaurus Nowinski, 1971; Janensch, 1935-1936; Nowinski, 1971 ) in addition to the large apical wear facet, as in MPEFPV 10606 (Fig. 1).

The combination of apomorphic characters (ovoid, narrowcrowned teeth, with prominent apical and reduced marginal wear facets) present in MPEF-PV 10606 is only found in basal titanosauriforms. The teeth of Titanosauria, the derived clade of Titanosauriformes, have (as in diplodocids) a circular cross section along the entire height of the crown, whereas basal titanosauriforms (e.g., Abydosaurus, Chure et al., 2010; Phuwiangosaurus, Suteethorn et al., 2009) have a slightly flattened apical region of the crown (as in MPEFPV 10606). The inclusion of MPEF-PV 10606 among basal Titanosauriformes is the most parsimonious hypothesis based on the morphology of the tooth, but should be considered with caution due to its implications for the neosauropod fossil record.

A placement of MPEF-PV 10606 within Titanosauriformes has implications for the timing of the initial diversification of Neosauropoda. Neosauropods were already highly diverse during the Late Jurassic, when the earliest undisputed neosauropod skeletal remains are known, including both basal macronarians (Camarasaurus, Brachiosaurus) and diplodocoids (Dicraeosaurus, Diplodocus). The origins of this group have long been suspected to be older than Late Jurassic. Some recent phylogenetic studies have placed basal neosauropods in the Middle Jurassic (e.g., BeIlusaurus Dong, 1990 (Carballido et al., 2013), Bellusaurus, Atlasaurus and Jobaria (Upchurch et al., 2004), pushing the diversification event of Neosauropoda into the Middle Jurassic. These hypotheses, however, are debated, given that some authors considered wide tracks cannot be unequivocally assigned to a certain clade (Henderson, 2006) and that the Middle Jurassic taxa mentioned above have been placed outside neosauropods in other phylogenetic studies (e.g., Wilson, 2002; Wilson and Upchurch, 2009). Furthermore, 
the above listed taxa are all probably late Middle Jurassic (Callovian) in age and thus still some ten million years younger than the tooth described here.

The presence of a narrow-crowned tooth of putative neosauropod affinities in the latest Early-Middle Jurassic Cañadón Asfalto Formation (Cúneo et al., 2013) adds new data to this debate and would set an even earlier time of origin for the modern lineages of neosauropods. Interestingly, a similar pattern of undetected early diversification has been recently proposed for other dinosaur groups based on discoveries from the Cañadón Asfalto Formation (Pol and Rauhut, 2012), which could be related with worldwide scarcity of dinosaur assemblages from the latest Early and Middle Jurassic (Mannion et al., 2011).

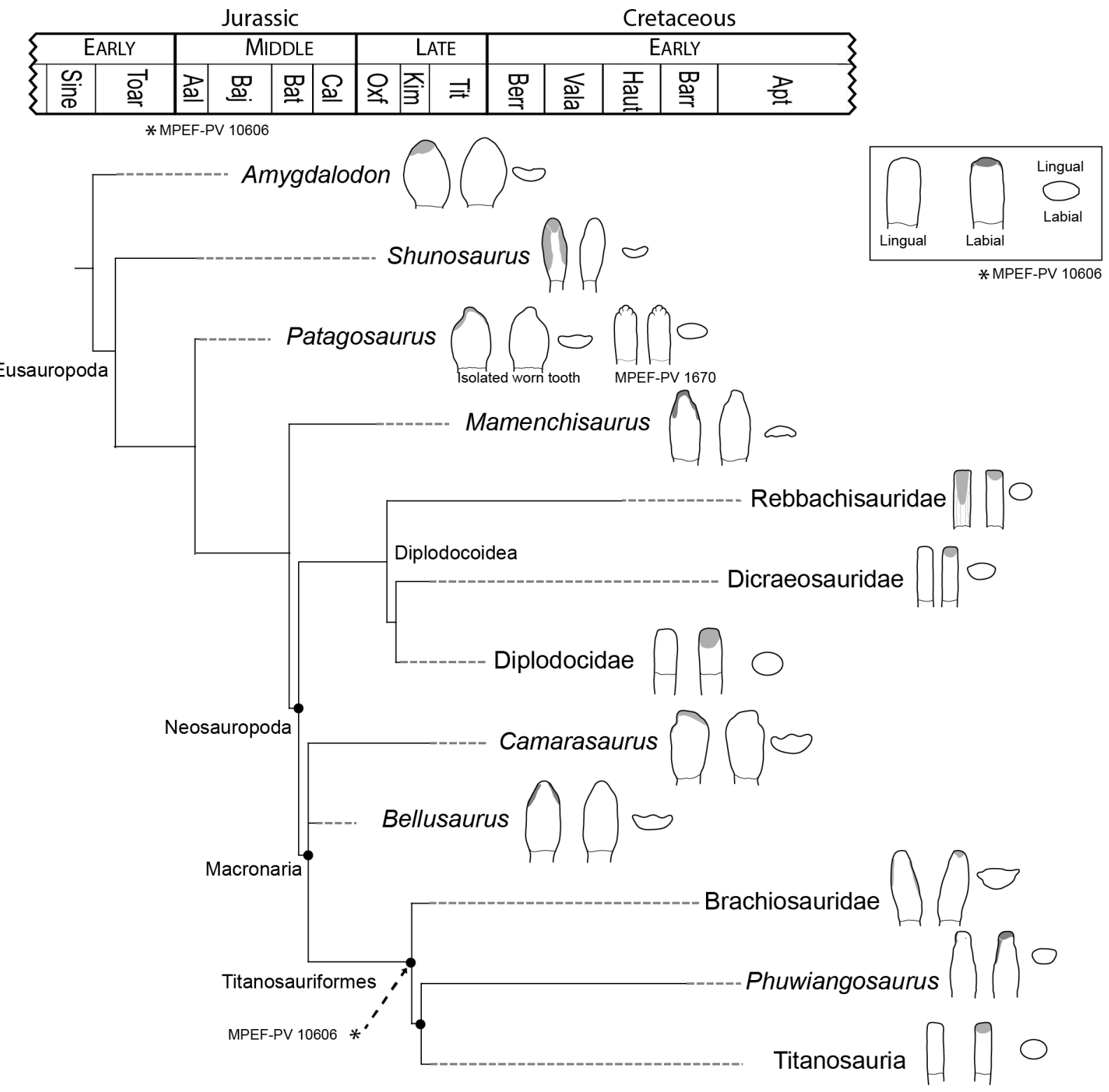

Figure 2. Simplified calibrated tree showing the different crown shapes and wear facets of several Jurassic and Cretaceous sauropod lineages, in lingual, labial and cross section. Most parsimonious hypothesis of MPEF-PV 10606 is showed with doted arrow. 
Basal eusauropod affinities. One of the possible phylogenetic positions of MPEF-PV 10606 is allied to some basal eusauropods, which would be more congruent from a stratigraphic point of view, but marginally suboptimal based on the character distribution in the parsimony analysis (see Supplementary Material). Although most basal (non-neosauropod) eusauropods have broad-crowned teeth, Shunosaurus and Mamenchisaurus from the Middle and Late Jurassic of China have relatively narrow-crowned teeth. These forms, however, have crowns that are D-shaped in cross section, with a convex labial surface and a concave lingual surface, differing from the ovoid cross section crown (with lingual and labial surfaces almost equally convex) of MPEF-PV 10606. Additionally, extensively worn teeth of Mamenchisaurus have, as in other basal eusauropods, well-developed v-shaped wear facets that extend as two distinct narrow surfaces on the distal and mesial margins of the crown, rather than having an extensive apical wear facet as in MPEFPV 10606. It must be noted that a single apical wear facet is present in first wear stages of Shunosaurus, but in heavily worn teeth of this taxon the facets are v-shaped and heavily extend along the mesial and distal margins (Chatterjee and Zheng, 2002). These two characters require extra steps in phylogenetic trees that depict MPEF-PV 10606 among basal eusauropods. As the crown is slightly worn, slightly marked mesial and distal wear facets cannot be completely ruled out. Nevertheless highly marked v-shaped wear facets were clearly absent in this specimen.

Although MPEF-PV 10606 differs from other basal eusauropods in the above-mentioned features, the presence of a neosauropod in the Cañadón Asfalto Formation would be surprising. None of the multiple sauropod postcranial remains that have been found in this unit (Bonaparte, 1986; Coria, 1994; Rauhut et al., 2001; Pol et al., 2009) have derived neosauropod features. Therefore, the slightly less parsimonious hypotheses that depict MPEF-PV 10606 as a basal (non-neosauropod) eusauropod with narrow and subcylindrical crowns should not be disregarded. One dentary (MACN-CH 933) and two maxillae (MACN-CH 934) with unerupted teeth, and several isolated teeth from the Cañadón Asfalto Formation were referred to the basal eusauropod Patagosaurus (Bonaparte, 1986). An additional dentary, without erupted teeth, but with visible unerupted crowns, was identified as being from Patagosaurus by Rauhut (2003; MPEF-PV 1670), who concluded that the maxillae cannot be properly assigned to this taxon. Among all known teeth referred to Patagosaurus, a wide morphological variation is evident, ranging from unexpanded crowns (see Rauhut, 2003; MPEF-PV 1670; MACN-CH 933) to broadcrowned teeth (Bonaparte, 1986; MACN-CH 934), which seems to indicate the presence of more than one taxon in the Cañadón Asfalto Formation (Rauhut, 2003; Pol et al., 2009; Holwerda et al., 2015). Actually, three tooth morphotypes were described by Holwerda et al. (2015) and a fourth one was recently added by Becerra et al. (in press.). Nevertheless, the tooth here described can be well differentiated from the spatulate and broad-crowned teeth described by Bonaparte (1986) and the cylindrical/triangular shape observed in the maxillae (MACN-CH 934), as well as all the isolated sauropod teeth collected from this unit and housed in MACN and MPEF collections. Moreover, the enamel wrinkling pattern differs slightly from that of the other known teeth from several localities from the Cañadón Asfalto Formation, in that they are neither rugose striated, nor pebbly patterned, as in the morphotypes described by Holwerda et al. (2015). Therefore, the tooth here described indicates the presence of a fifth tooth morphotype in the Cañadón Asfalto Formation.

The crown morphology of MPEF-PV 10606 (labially and lingually convex) resembles in some way the teeth of the dentaries MACN-CH 933 and MPEF-PV 1670, which are clearly assigned to Patagosaurus (Holwerda et al., 2015). However, whereas in MPEF-PV 10606 the crown-root limit is well marked, in MPEF-PV 1670 the enamel gently disappears into the root without forming a clear limit, whereas the crownroot limit cannot be observed in MACN-CH 933. Worn teeth neither are preserved in MPEF-PV 1670, nor in MACN-CH 933 dentary, precluding comparisons between the wear facets of MPEF-PV 10606 with non-isolated teeth assigned to Patagosaurus. Finally, the tooth here described can be well differentiated from all the worn teeth collected from this unit, which are well spatulated with v-shaped wear facets (e.g., MACN 2008; MPEF-PV 3060), but without a single wear facet.

Despite the tooth MPEF-PV 10606 resembling in some features the teeth of some basal sauropods, even those from the dentaries assigned to Patagosaurus, it can be well 
differentiated from them by one or more characters. Thus, if MPEF-PV 10606 indeed belongs to a yet unknown lineage of basal eusauropods with mesiodistally unexpanded crowns, convex labial and lingual surfaces, and single apical wear, which occurs together with mesial and distal wear facets, it would imply that this morphology (and jaw mechanics; see below) convergently appeared two times in the evolutionary history of sauropods: in Titanosauriformes (see below), and a lineage of basal sauropods solely represented by the tooth here described. It must be noted here that a similar morphology could be present at least in the Patagosaurus dentaries crowns, which are solely differentiated from the tooth here described in that the crown-root limit diminishes gently and is not abrupt.

\section{Significance of MPEF-PV 10606 for the Cañadón Asfalto fauna}

Irrespective of the phylogenetic affinities of MPEF-PV 10606, its presence in the Cañadón Asfalto Formation indicates that the large range of sauropod crown breadths, previously noted only for the Late Jurassic (Chure et al., 2010), was already present by the latest Early Jurassic. This is significant because different tooth morphologies and wear patterns have been interpreted as indicating different jaw mechanics (Calvo, 1994), and thus, probably, differences in diet. The broad overlapping crowns with extensive v-shaped wear facets of basal eusauropods indicate that the lower and upper tooth row have an interlocking type of occlusion (Chatterjee and Zheng, 2002). In contrast, the narrow and non-overlapping crowns with planar apical wear facets of derived neosauropods indicate that the upper and lower teeth met in a one-to-one fashion (Chure et al., 2010). Therefore, the differences between the crown morphology and wear facets of MPEF-PV 10606, and other forms from the Cañadón Asfalto Formation (i.e., broad crowned teeth with V-shaped wear facets of teeth assigned to Patagosaurus by Bonaparte (1986), a new undescribed sauropod (Pol et al., 2009), and the isolated tooth recently described (Becerra et al., in press) indicate a diversity in jaw mechanics within the sauropods from this unit. This diversity of forms can be interpreted as an early evidence of niche partitioning within a sauropod fauna in the late Early Jurassic, as has been suggested for the broad and narrow toothed sauro- pods from the Late Jurassic Morrison Formation (Calvo, 1994). Further studies of the whole material assigned to Patagosaurus, including the different tooth morphologies, are needed in order to better understand how diverse the sauropod fauna from this unit really was.

\section{ACKNOWLEDGEMENTS}

We thank Aluar Aluminio Argentino SAIC and J. Groizard for access to SEM lab. L. Reyner, L. Canessa for preparation and technical assistance, and the Secretary of Culture from Chubut Province for authorizing fieldwork. The comments made by the reviewers ( $A$. Otero and P. Gallina) improved this manuscript. This work was supported by ANPCYT PICT 1756 and 0808 (DP) and 0668 (JLC), DFG RA 1012/9-1 (OWMR) and the National Science Foundation (NSF, U.S.A.), under Grants DEB 0946430 and DEB 1068089 (to G. Rougier).

\section{REFERENCES}

Allain, R., and Aquesbi, N. 2008. Anatomy and phylogenetic relationships of Tazoudasaurus naimi (Dinosauria, Sauropoda) from the late Early Jurassic of Morocco. Geodiversitas 30: 345-424.

Barrett, P.M., and Upchurch, P. 2005. Sauropodomorph diversity through time. Paleoecological and macroevolutionary implications. In: K.C. Rogers, and J. Wilson (Eds.), The Sauropods: Evolution and Paleobiology. University of California Press, California, p. $125-126$.

Becerra, G.M., Gómez, K.L., and Pol, D. In press. A sauropodomorph tooth increase the diversity of dental morphotypes in the Cañadón Asfalto Formation (Early-Middle Jurassic) of Patagonia. Comptes Rendus Palevol.

Bonaparte, J.F. 1986. Les Dinosaures (Carnosaures, Allosauridés, Sauropodes, Cétiosauridés) du Jurassique Moyen de Cerro Cóndor (Chubut, Argentine). Annales de Paléontologie 72: 325-386.

Calvo, J.O. 1994. Jaw mechanics in sauropod dinosaurs. Gaia 10: 183-193.

Carballido, J.L., and Pol, D. 2010. The dentition of Amygdalodon patagonicus (Dinosauria: Sauropoda) and the dental evolution in basal sauropods. Comptes Rendus Palevol 9: 83-93.

Carballido, J.L., Salgado, L., Pol, D., Canudo, J.I., and Garrido, A. 2013. A new basal rebbachisaurid (Sauropoda, Diplodocoidea) from the Early Cretaceous of the Neuquén Group; evolution and biogeography of the group. Historical Biology 24: 631-654.

Carballido, J.L., Pol, D., Otero, A., Cerda, I.A., Salgado, L., Garrido, C.A., Ramezani, J., Cúneo, N.R., and Krause J.M. 2017. A new giant titanosaur sheds light on body mass evolution among sauropod dinosaurs. Proceedings of the Royal Society B: Biological Sciences 284: 2017-1219.

Chatterjee, S., and Zheng, Z. 2002. Cranial anatomy of Shunosaurus, a basal sauropod dinosaur from the Middle Jurassic of China. Zoological Journal of the Linnean Society 136: 145-169.

Chure, D., Britt, B., Whitlock, J.A., and Wilson, J.A. 2010. First complete sauropod dinosaur skull from the Cretaceous of the Americas and the evolution of sauropod dentition. Naturwissenschaften 97: 379-391.

Coria, A.R. 1994. On monospecific assembladge of sauropod dinosaurs from Patagonia: Implications for gregarious behaviour. Gaia 10: 209-213.

Cúneo, R., Ramezani, J., Scasso, R., Pol, D., Escapa, I., Zavattieri, A.M., 
and Bowring, A.A. 2013. High-precision U-Pb geochronology and a new chronostratigraphy for the Cañadón Asfalto Basin, Chubut, central Patagonia: Implications for terrestrial faunal and floral evolution in Jurassic. Gondwana Research 24: 12671275.

Galton, P.M. 1985. Diet of prosauropod dinosaurs from the late Triassic and early Jurassic. Lethaia 18: 105-123.

Henderson, M.H. 2006. Burly gaits: centers of mass, stability, and the trackways of sauropod dinosaurs. Journal of Vertebrate $\mathrm{Pa}$ leontology 26: 907-921.

Holwerda, F.M., Pol, D., and Rauhut, O.W.M. 2015. Using dental enamel wrinkling to define sauropod tooth morphotypes from the Cañadón Asfalto Formation, Patagonia, Argentina. PLoS ONE 10, e0118100. doi:10.1371/journal.pone.0118100

Janensch, W. 1935-1936. Die Schädel der Sauropoden Brachiosaurus, Barosaurus und Dicraeosaurus aus den TendaguruSchichten Deutsch-Ostafrikas. Palaeontographica 7: 147-298.

Madsen, J.H., McIntosh, J.S., and Berman, D.S. 1995. Skull and atlas-axis complex of the Upper Jurassic sauropod Camarasaurus Cope (Reptilia: Saurischia). Bulletin of the Carnegie Museum of Natural History 31: 1-115.

Mannion, P.D., Upchurch, P., Carrano, M.T., and Barrett, P.M. 2011. Testing the effect of the rock record on diversity: a multidisciplinary approach to elucidating the generic richness of sauropodomorph dinosaurs through time. Biological Reviews 86: 157-181.

Nowinski, A. 1971. Nemegtosaurus mongoliensis n. gen., n. sp., (Sauropoda) from the uppermost Cretaceous of Mongolia. Palaeontologica Polonica 25: 57-81.

Ouyang, H., and Ye, Y. 2002. The First Mamenchisaurian Skeleton with Complete Skull: Mamenchisaurus youngi. In: Sichuan Science and Technology Press, Chengdu, 88 p. [in Chinese with English summary].

Pol, D., and Rauhut, O.W.M. 2012. A Middle Jurassic abelisaurid from Patagonia and the early diversification of theropod dinosaurs. Proceedings of the Royal Society B: Biological Sciences 279: 3170-3175.

Pol, D., Rauhut, O.W.M., and Becerra, M. 2011. A Middle Jurassic heterodontosaurid dinosaur from Patagonia and the evolution of heterodontosaurids. Naturwissenschaften 98: 369-379.

Pol, D., Rauhut, O.W.M., and Carballido, J.L. 2009. Skull anatomy of a new basal eusauropod from the Cañadón Asfalto formation (Middle Jurassic) of central Patagonia. Journal of Vertebrate Paleontology 29: 165A.

Rauhut, O.W.M. 2003. A dentary of Patagosaurus (Sauropoda) from the Middle Jurassic of Patagonia. Ameghiniana 40: 425-432.

Rauhut, O.W.M., López-Arbarello, A., Puerta, P., and Martin, T. 2001. Jurassic vertebrates from Patagonia. Journal of Vertebrate $P a-$ leontology 21: $91 \mathrm{~A}$.

Rauhut, O.W.M., Martin, T., Ortíz-Jaureguizar, E., and Puerta, P. 2002. A Jurassic mammal from South America. Nature 416: $165-168$.
Remes, K. 2006. Revision of the Tendaguru sauropod dinosaur Torneria africana (Fraas) and its relevance for sauropod Paleobiogeography. Journal of Vertebrate Paleontology 26: 651-669.

Rougier, G.W., Martinelli, A.G., Forasiepi, A.M., and Novacek, M.J. 2007. New Jurassic mammals from Patagonia, Argentina: a reappraisal of australosphenidan morphology and interrelationships. American Museum Novitates 3566: 1-54.

Salgado, L., and Calvo, J.O. 1997. Evolution of titanosaurid sauropods. II: The cranial evidence. Ameghiniana 34: 38-48.

Sterli, J. 2008. A new, nearly complete stem turtle from the Jurassic of South America with implications for turtle evolution. Biology Letters 4: 286-289.

Suteethorn, S., Le Loeuff, J., Buffetaut, E., Suteethorn, V., Talubmook, C., and Chonglakmani, C. 2009. A new skeleton of Phuwiangosaurus sirindhornae (Dinosauria, Sauropoda) from NE Thailand. Geological Society, London, Special Publications 315: 189-215.

Upchurch, P. 1998. The phylogenetic relationships of sauropod dinosaurs. Zoological Journal of the Linnean Society 124: 43-103.

Upchurch, P., and Barrett, P.M. 2000. The evolution of sauropod feeding mechanisms. In: H.D. Sues (Ed.), Evolution of Herbivory in Terrestrial Vertebrates: Perspectives from the Fossil Record. Cambridge University Press, Cambridge, p. 79-122.

Upchurch, P., Barrett, P.M., and Dodson, P. 2004. The Sauropods. In: D.B. Weishampel, P. Dodson, and H. Osmólska (Eds.), Dinosaurs. University of California, Berkley, p. 259-354.

Wilson, J.A. 2002. Sauropod dinosaur phylogeny: critique and cladistic analysis. Zoological Journal of the Linnean Society 136 : 215-275.

Wilson, J.A., and Upchurch, P. 2009. Redescription and reassessment of the phylogenetic affinities of Euhelopus zdanskyi (Dinosauria: Sauropoda) from the Early Cretaceous of China. Journal of Systematic Palaeontology 7: 199-239.

Wilson, J.A., and Sereno, P.C. 1998. Early evolution and higher-level phylogeny of sauropod dinosaurs. Memoir of the Society of Vertebrate Paleontology 5: 1-68.

Yates, A.M. 2007. The first complete skull of the Triassic dinosaur Melanorosaurus haughton (Sauropodomorpha: Anchisauria). Special Papers in Palaeontology 77: 9-55.

Doi: 10.5710/PEAPA.17.11.2017.249

Recibido: 4 de octubre de 2017

Aceptado: 17 de noviembre de 2017 